\title{
Microbial Succession and Chemical Characteristics in Fermentation of Ambonese arrack (Sopi), Traditional Beverage from Maluku
}

\author{
Ferymon Mahulette $^{1^{*}}$, Dea Indriani Astuti ${ }^{2}$ \\ ${ }^{1}$ Biology Education Study Program, Faculty of Teacher Training and Education, Universitas Pattimura, Indonesia \\ ${ }^{2}$ School of Life Sciences and Technology, Institut Teknologi Bandung, Indonesia \\ *Email: ferymonm@gmail.com
}

Submitted: 19 March 2020. Revised: 10 April 2020. Accepted: 1 June 2020

\begin{abstract}
Ambonese arrack is one of the traditional fermented beverage product in Maluku, Indonesia. The microbiological research of this beverage that is processed using coconut sap as raw material has never been done before. The research aimed to analyze the microbial succession and chemical characteristics during fermentation of Ambonese arrack. The sample of coconut sap was taken from traditional producer in Mahia village, Ambon. The dominant microbes in the fermentation of Ambonese arrack were Pichia polymorpha and Kloeckera javanica. The highest numbers of these two microbes was obtained after 15 hours fermentation $(9.6 \log \mathrm{Cfu} / \mathrm{mL}$ and 9.9 $\mathrm{Cfu} / \mathrm{mL}$, respectively). The sugar content decreased from $593.3 \mathrm{mg} / \mathrm{L}$ to $474.3 \mathrm{mg} / \mathrm{L}$, whereas ethanol content increased from $0.0018 \mathrm{~g} / \mathrm{L}$ to $0.0100 \mathrm{~g} / \mathrm{L}$. The $\mathrm{pH}$ value decreased from 4.70 to 3.10. The research has isolated indigenous microbes in Ambonese arrack fermentation which was considered as novelty. The bacteria that play a role in fermentation can be used as a starter in the fermentation of various beverage products, especially Ambonese arrack. The results of this research can improve the quality of this fermentation product in the future.
\end{abstract}

Key words: Ambonese Arrack; Coconut Sap; Ethanol Content; Microbial Succession

How to Cite: Mahulette, F., \& Astuti, D. I. (2020). Microbial succession and chemical characteristics in fermentation of Ambonese arrack (sopi), traditional beverage from Maluku. Biosaintifika: Journal of Biology \& Biology Education, 12 (2), 147-154

DOI: http://dx.doi.org/10.15294/biosaintifika.v12i2.23791

\section{INTRODUCTION}

Processing alcoholic beverages by fermentation is a tradition that has been going on for a long time in various parts of the world (Ohimain, 2016). Some regions in eastern Indonesia, such as Manado, Makassar and Maluku often consume this type of drink. One of the beverage product that is very popular in Maluku community is Ambonese arrack (locally named sopi). Besides being used as a drink to increase spirit for work, this drink is also used in various traditional ceremonies, so that it is considered as a symbol of friendship in the life of Maluku people (Gunawan, 2019). In other regions, people believe that the drink act to "strengthen of blood" and as an aphrodisiac (Chaves-Lopez et al., 2014)

Ambonese arrack is product of distillation of palm sap which has been fermented for more than a day. The palm sap (locally named sageru) is the sweet, oysterwhite coloured sap collected from the immature palm spadix (inflorescence) (Sudha et al., 2019). It is a rich source of simple sugars, such as sucrose, glucose, fructose and maltose (Law et al., 2011), The saps used in processing Ambonese arrack are from coconut (Cocos nucifera L), sugar palm (Arenga pinnata Merr) or koli (Borassus sundaicus Becc). The Maluku people more often use coconut sap to make
Ambonese arrack because coconut plants grow a lot in this area. Ambonese arrack processing using koli sap only by the people of Southwest Maluku (Sahusilawane et al., 2015). Besides being used to make Ambonese arrack, it could also be used as a yeast starter for bread making (Olowonibi, 2017). The palm sap that has been fermented can be distilled to produce Ambonese Arrack. If it is not distilled, the palm sap will produce sagero vinegar

The fermentation process of alcoholic beverages involves microbes (Escalante et al., 2008). Coconut sap used as a raw material contains yeast and bacteria. The composition of these microbes is largely determined by environmental conditions. Generally the dominant yeast in palm sap is Saccharomyces (Chandrasekhar et al., 2012), but in different places it is dominated by other species (Kalaiyarasi et al., 2013). Microbial composition is greatly influences the chemical characteristics which include sugar content, ethanol content, and acidity during palm sap fermentation. Ambonese arrack processing is still carried out on a household scale and it is not controlled. The equipment used in processing is also not aseptic, so it is possible to have microbial contaminants involved during fermentation. Contaminant microbes can reduce the quality of arrack flavour (Belda et al., 2017). This study aimed to analyze microbial succession and 
changes of chemical characteristics during the fermentation of Ambonese arrack. The dominant isolates that play a role in the fermentation of Ambonese arrack can be used as a starter in the processing of various fermented beverages.

\section{METHODS}

\section{Ambonese arrack Sampling}

A total of $5 \mathrm{~L}$ coconut (Cocos nucifera $\mathrm{L}$ ) sap was taken from Mahia Village, Ambon City, then put in a cooler box and brought to the laboratory. The sap allowed to ferment for 21 hours. Analysis was done every 3 hours. At the end of fermentation, the sap which has undergone fermentation was distilled using a traditional distilator into Ambonese arrack and then ethanol content was measured using a Gas Chromatography-Mass Spectrophotometer (GC-MS). Microbiological analysis and chemical characteristics were carried out at Basic Chemistry Laboratory Pattimura University, while microbial identification in Ambonese arrack fermentation was carried out at the Mirobiology Laboratory of Bandung Institute of Technology

\section{Isolation and Identification Microbes in Ambonese arrack Fermentation}

A total of $1 \mathrm{~mL}$ of sample was diluted serially using $0.85 \%$ saline solution. A total of $100 \mu \mathrm{L}$ of the diluted sample was inoculated on Nutrient Agar (NA) for total bacterial count and Potato Dextrose Agar (PDA) containing $0.05 \mathrm{mg}$ chloramphenicol for total yeast count, respectively, using the spread plate technique with a sterile L-shape glass rod then incubated at $37^{\circ} \mathrm{C}$ for 24 hours (Gberikon et al., 2016). All colonies were purified on the same medium until pure colonies that considered as isolates were obtained. The colonies that had different macroscopic characteristics were observed for microscopic characteristics and biochemical tests.

\section{Analysis of Chemical Characteristics}

Measurement of ethanol content was carried out by the redox titration method (Asakai \& Hioki, 2011). A total of $10 \mathrm{~mL}$ dichromic acid solution $(0.01 \mathrm{M}$ $\mathrm{K}_{2} \mathrm{Cr}_{2} \mathrm{O}_{3}$ in $5 \mathrm{M} \mathrm{H}_{2} \mathrm{SO}_{4}$ ) was put into a $250 \mathrm{~mL}$ Erlenmeyer flask. Sample that has been diluted 10 times was pipetted into small vial tube and placed hanging in Erlenmeyer flask. The Erlenmeyer flask was closed and incubated for 18 hours at room temperature. After incubation, the liquid sample in a small vial tube was removed. A total of $100 \mathrm{~mL}$ distilled water and $1 \mathrm{~mL}$ of potassium iodide (KI) $1.2 \mathrm{M}$ were added to the Erlenmeyer flask and then shaken until it turned brown. This solution was titrated with $0.03 \mathrm{M}$ sodium thiosulfate $\left(\mathrm{Na}_{2} \mathrm{~S}_{2} \mathrm{O}_{3}\right)$ until the color of the solution turned yellow, then $1 \mathrm{~mL}$ of $1 \%$ starch solution was added, so that the color of the solution turned dark blue. The solution was titrated using sodium thiosulfate until the solution turned clear light blue. Ethanol content $(\mathrm{g} / \mathrm{L})$ was calculated by the formula: Ethanol $(\mathrm{g} / \mathrm{L})=[\mathrm{Vol}$ (B-S)/1000] x [(mol thiosulfate $\times \mathrm{M}_{\mathrm{r}}$. ethanol $\mathrm{x}$ dilution)/4. Vol. B was the volume of $\mathrm{Na}_{2} \mathrm{~S}_{2} \mathrm{O}_{4}$ used in the blank titration, whereas vol. S was the volume of $\mathrm{Na}_{2} \mathrm{~S}_{2} \mathrm{O}_{4}$ used in the sample titration.

For sugar content measurement. A total $2 \mathrm{~mL}$ of sample was added by 1.6 Somogyi I solution and 0.4 Somogyi II solution then it was put into a water bath for 10 minutes. The solution was then cooled in ice for 5 minutes then added with $2 \mathrm{~mL}$ of Nelson solution and $4 \mathrm{~mL}$ of distilled water. The solution was measured for its absorbance at a wavelength of 520 $\mathrm{nm}$ (Barlianti et al., 2015). The measurement of $\mathrm{pH}$ was using a pH meter (CT-6022, Shenzhen Kedida Electronic, China).

\section{RESULTS AND DISCUSSION}

\section{Microbes in Ambonese Arrack Fermentation}

The traditional Ambonese arrack is a mixed culture fermentation beverage product. In the mixed culture, some yeasts and bacteria interact to convert the coconut sap into tuak (fermented sap) and then it was distilled into Ambonese arrack. Generally, the fermentation of Ambonese arrack took place for no more than one day. A total of 8 selected isolates (5 bacterial isolates and 3 yeasts isolates) with different characteristics were isolated and identified during Ambonese arrack fermentation. The five bacterial isolates were identified as Bacillus firmus, B. cereus, B. laterosporus, B. brevis and Serratia odorifera, while 3 yeasts isolates were identified as Pichia polymorpha, Kloeckera javanica, and Nadsonia elongata (Figure 1).

All bacteria isolates were rod shapes and motile. These isolates were also Gram positive and spore forming, except IS-03 isolate. All isolates were capable of hydrolyzing casein and gelatin. These isolates were also produce catalase enzyme. All isolates did not produce $\mathrm{H}_{2} \mathrm{~S}$, except IS-04 isolate (Table 1). 


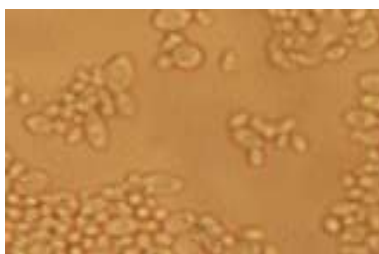

(a)

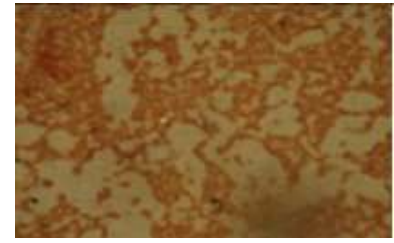

(e)

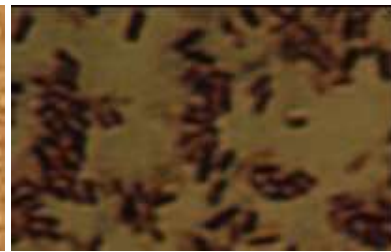

(b)

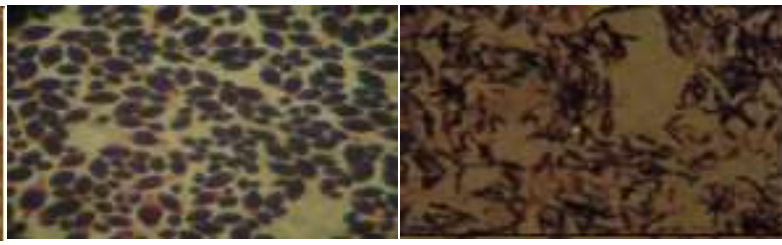

(f)

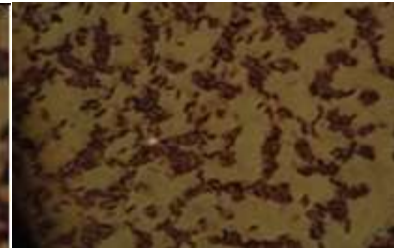

(c)

(g)

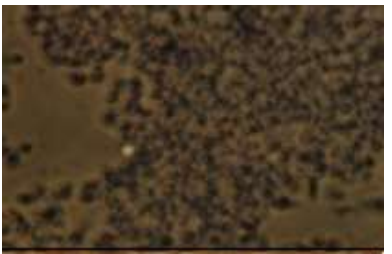

(d)

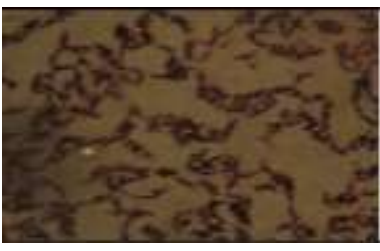

(h)

Figure 1. Microbes in Ambonese arrack fermentation. P. polymorpha (a), B. firmus (b), B. cereus (c), N. elongata (d), S. odorifera (e), K. javanica (f), B. laterosporus (g),B. brevis (h). Magnification 400x for yeast and 1000x for bacteria.

Table 1. Identification of bacteria isolates during Ambonese arrack fermentation

\begin{tabular}{|c|c|c|c|c|c|}
\hline \multirow{2}{*}{ Characteristics } & \multicolumn{5}{|c|}{ Isolates } \\
\hline & IS-01 & IS-02 & IS-03 & IS-04 & IS-05 \\
\hline $\begin{array}{l}\text { Macroscopic } \\
\text { (colony) }\end{array}$ & $\begin{array}{c}\text { Irregular, } \\
\text { lobate, opaque }\end{array}$ & $\begin{array}{l}\text { Cicular, ser- } \\
\text { rate,opaque }\end{array}$ & $\begin{array}{l}\text { Irregular, fila- } \\
\text { mentous }\end{array}$ & $\begin{array}{c}\text { Irregular,un- } \\
\text { du- } \\
\text { late,opaque }\end{array}$ & $\begin{array}{c}\text { Irregular, } \\
\text { entire, } \\
\text { opaque }\end{array}$ \\
\hline Cell shape & Rod & Rod & Rod & Rod & Rod \\
\hline Gram Staining & + & + & - & + & + \\
\hline Spore forming & + & + & - & + & + \\
\hline Motility & + & + & + & + & + \\
\hline Starch hydrolysis & - & - & - & + & + \\
\hline Fat hydrolysis & - & - & + & - & - \\
\hline Casein hydrolysis & + & + & + & + & + \\
\hline Gelatin hydrolysis & + & + & + & + & + \\
\hline Glucose hydrolysis & + & + & + & + & - \\
\hline Sucrose hydrolysis & + & + & + & + & - \\
\hline Lactose hydrolysis & - & - & + & + & - \\
\hline $\mathrm{H}_{2} \mathrm{~S}$ production & - & - & - & + & - \\
\hline Indole production & - & - & + & + & + \\
\hline Urease production & - & - & + & + & - \\
\hline Catalase production & + & + & + & + & + \\
\hline Methyl red test & + & + & + & + & - \\
\hline Voges-Proskauer test & + & + & + & - & + \\
\hline TSI test & + & + & + & + & - \\
\hline Simmon's citrate test & - & - & + & + & + \\
\hline Nitrate reduction & + & - & + & + & + \\
\hline Result & B.laterosporus & B. brevis & S.odorifera & B.cereus & B. firmus \\
\hline
\end{tabular}

All yeast isolates have circular shaped colonies and sexually reproduced using ascospores. The IS-06 and IS-08 isolates reproduce by multipolar budding, while the IS-07 isolate by bipolar budding. All isolates were capable of hydrolyzing glucose, sucrose, mannose, and fructose. Xylose and arabinose were only hydrolyzed by IS-06 isolate (Table 2). 
Table 2. Identification of yeast isolates during Ambonese arrack fermentation

\begin{tabular}{lccc}
\hline \multirow{2}{*}{ Characteristics } & \multicolumn{3}{c}{ Isolates } \\
\cline { 2 - 4 } Macroscopic (Colony) & $\begin{array}{c}\text { Circular, undulate, } \\
\text { opaque, unpigmented } \\
\text { Cylindrical }\end{array}$ & $\begin{array}{c}\text { Circular, entire, } \\
\text { opaque, unpigmented } \\
\text { Ovall shape }\end{array}$ & $\begin{array}{c}\text { Circular, serrate, opaque, } \\
\text { cream } \\
\text { Ovale,cylindrical- } \\
\text { elongated }\end{array}$ \\
Budding type & Multipolar & Bipolar & Multipolar \\
Spore production & Ascospore & Ascospore & Ascospore \\
Glucose hydrolysis & + & + & + \\
Sucrose hydrolysis & + & + & + \\
Lactose hydrolysis & + & - & + \\
Galactose hydrolysis & + & - & - \\
Maltose hydrolysis & + & - & + \\
Mannose hydrolysis & + & + & + \\
Fructose hydrolysis & + & + & + \\
Xylose hydrolysis & + & - & - \\
Arabinose hydrolysis & + & - & + \\
Inositol hydrolysis & - & - & + \\
Sorbitol hydrolysis & - & K. javanica & . elongata \\
\hline Result & P. polymorpha & & + \\
\hline
\end{tabular}

Bacteria and yeasts found during Ambonese arrack fermentation had occurred succession (Figure 2). Succession was a change in the composition of microbes as the increase of fermentation time. The most dominant microbes in the fermentation of Ambonese arrack were yeasts, $P$. polymorpha and $K$. javanica. Both of these microbes play a role from the beginning of fermentation ( 0 hour) to the end of fermentation (21 hours). The highest numbers of these two microbes were $9.6 \log \mathrm{Cfu} / \mathrm{mL}$ and $9.9 \mathrm{Cfu} / \mathrm{mL}$, respec- tively at 15 hours of fermentation. Pichia and Kloeckera are microbes normally found in toddy fermentation, a type of palm wine from Sri Lanka that uses coconut sap as a raw material (Kalaiyarasi et al., 2013). Coconut sap contains sucrose and trace amount of reducing sugars including glucose, fructose, maltose and raffinose (Law et al., 2011). Pichia plays a role to ferment sucrose followed by the fermentation of fructose and others reducing sugar by Kloeckera (Kalaiyarasi et al., 2013).

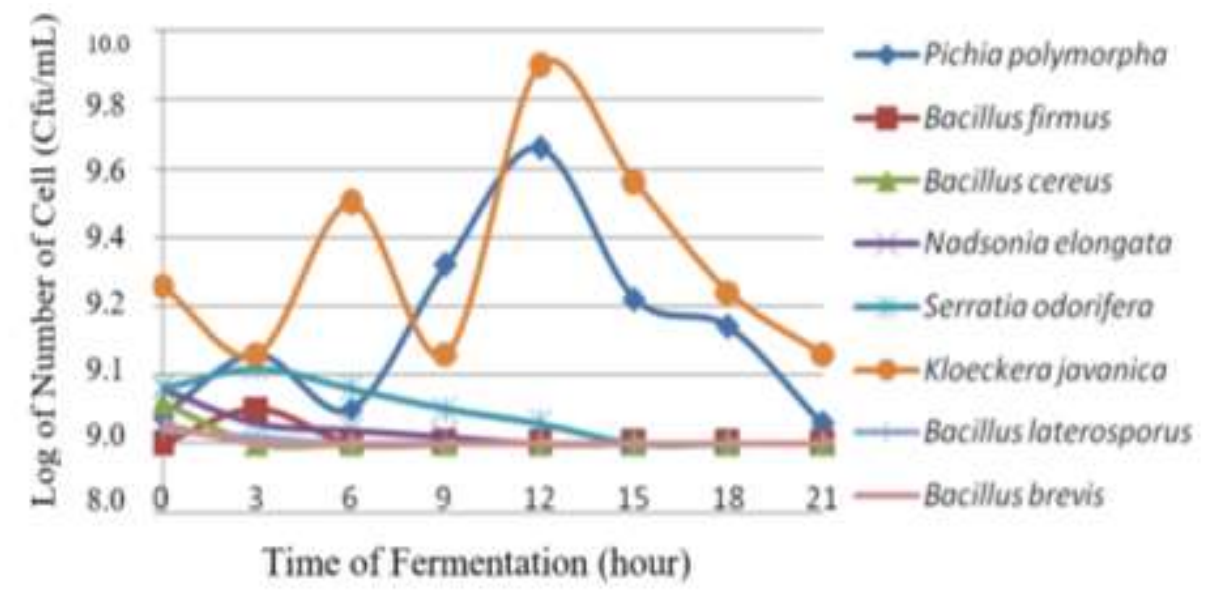

Figure 2. Succession of microbes during Ambonese arrack fermentation

\section{Microbial Succession in Ambonese Arrack Fermen- tation}

The patterns of microbial succession in traditionally fermented beverages are very diverse. This was influenced by geographical conditions. Diverse geographical locations contribute to the diverse compositions and changes of microbes during fermentation
(Zhu et al., 2018). Pichia polymorpha and Kloeckera javanica were found to be dominant at the beginning to the end of Ambonese arrack fermentation because these two microbes were able to produce ethanol by utilizing the sugar contained in the sap (Chandrasena et al., 2006). Kloeckera was a yeast that inhabit the highlands and it was very tolerant at low temperatures 
(Albertin et al., 2016). This characteristic causes Kloeckera to dominate Ambonese arrack fermentation that usually carried out by the people who live on the mountains of Ambon Island.

Bacillus was also found at the beginning of Ambonese arrack fermentation. This genus was dominated by Bacillus cereus and B. firmus. The characteristics of these two bacteria are gram-positive, facultative anaerobes, and spore forming. B. cereus and B. firmus were usually found in soil and cause food poisoning (Nair \& Raja, 2018). Bacillus is the predominant bacteria genus in coconut sap fermentation (Law et al., 2011). If they form spores, these bacteria can survive for a long time in alcoholic beverage products (Kim et al., 2014). B. cereus and B. firmus were often found in toddy fermentation (Vengadaramana et al., 2016). Both of these microbes play a role in producing acidic compounds by utilizing the sugar contained in the sap.

The presence of B. cereus and B. firmus were only at the beginning of fermentation because they were intolerant of decreasing $\mathrm{pH}$. The $\mathrm{pH}$ value had reached 4.3 at 6 hours of fermentation. The minimum $\mathrm{pH}$ value for growth of B. cereus was 4.9 (Okanlawon et al., 2010). The decrease of $\mathrm{pH}$ also greatly inhibits B. firmus as alkalophilic bacteria (Roosdiana et al., 2013). Thus, acidity in the medium limits the growth of these microbes at a later stage of fermentation. Several types of Bacillus have the enzyme cysteine desulfurase which can break down the cysteine into hydrogen sulfide (Albrecht et al., 2011). Hydrogen sulfide $\left(\mathrm{H}_{2} \mathrm{~S}\right)$ was a compound that reduces the sensory quality of traditionally fermented beverages (Bekker et al., 2016).

Another bacterium found in Ambonese arrack fermentation was Serratia odorifera. This bacterium is pathogenic and often found in the sap fermentation (Chandrasekhar et al., 2012). The presence of Bacillus and Serratia were only at the beginning of fermentation, so they were considered as contaminant bacteria. Serratia is a rod-shaped, aerobic bacterium that has proteolytic activity and often found in food. This bacteria population usually increases in the initial stages of wine fermentation. Serratia can produce acidic compounds (Sabri et al., 2011). The growth of this bacterium was more adaptive to acidic conditions than other bacteria. It was a characteristic that cause Serratia to able to survive until the 12 hour during the traditional fermentation of Ambonese arrack. The processing of this traditional beverage must also be carried out aseptically to reduce the amount of contaminant bacteria in the fermentation process.

\section{Chemical Characteristics of Ambonese Arrack Fermentation}

Generally, the growth of all microbes decreased after 12 hours in Ambonese arrack fermentation. This decrease was due to nutrition in the sap, especially the diminishing sugars. Reducing sugars content decreased from of $593.3 \mathrm{mg} / \mathrm{L}$ at 0 hours to $474.3 \mathrm{mg} / \mathrm{L}$ at 21 hours (Figure 3a). The decreasing of reducing sugars during the fermentation of Ambonese arrack also decreased the microbial growth. Decreasing of reducing sugars because it was used by yeast and bacteria, especially Bacillus (Kleijn et al., 2010).

The decreasing of the numbers of microbes was also caused by the accumulation of alcohol and acid content because fermentation took place in batch culture. The ethanol content during fermentation was increasing from $0.0018 \mathrm{~g} / \mathrm{L}$ at the beginning to 0.0100 $\mathrm{g} / \mathrm{L}$ at 21 hours of fermentation (Figure $3 \mathrm{~b}$ ). Traditional fermentation involving many microbes, not only ethanol producer, so that ethanol production was rather low (Nwaiwu \& Itumoh, 2017). At the beginning of fermentation, the increase of ethanol content took place rather slowly because the sugar contained in the sap was also utilized by bacteria to produce organic acid compounds. This increase was sharp after 9 hours of fermentation synchronize with the increasing growth of $P$. polymorpha and $K$. javanica. At the end stages, ethanol content tended not to increase due to the lower $\mathrm{pH}$ of the fermentation medium and the growth of ethanol producer microbes that had decreased. A low $\mathrm{pH}$ value can inhibit the enzyme activity in yeast to produce ethanol (Le \& Le, 2014). The decrease of the numbers of microbes due to high alcohol content was toxic which inhibits cell growth and damages the microbial cell wall (Danmadami et al., 2017). After distilation using traditional destilator, the ethanol content of Ambonese arrack was $28.93 \%$.

The $\mathrm{pH}$ value was a significantly decreased from 4.70 at the beginning to 3.10 at 21 hours of fermentation because the accumulation of acids compounds (Figure 3c). The acidic compounds were produced by acid-producing bacteria which cause a decrease in $\mathrm{pH}$ in the initial stage. In the middle to late stages, the decrease of $\mathrm{pH}$ was caused by yeast metabolism which has increased after 12 hours of fermentation. Traditional fermentation involves many microbes capable of producing organic acid compounds (Danmadami et al., 2017). After distilation using traditional destilator, the $\mathrm{pH}$ of Ambonese arrack was 3.38. The $\mathrm{pH}$ value causes this product has a rather sour taste. 


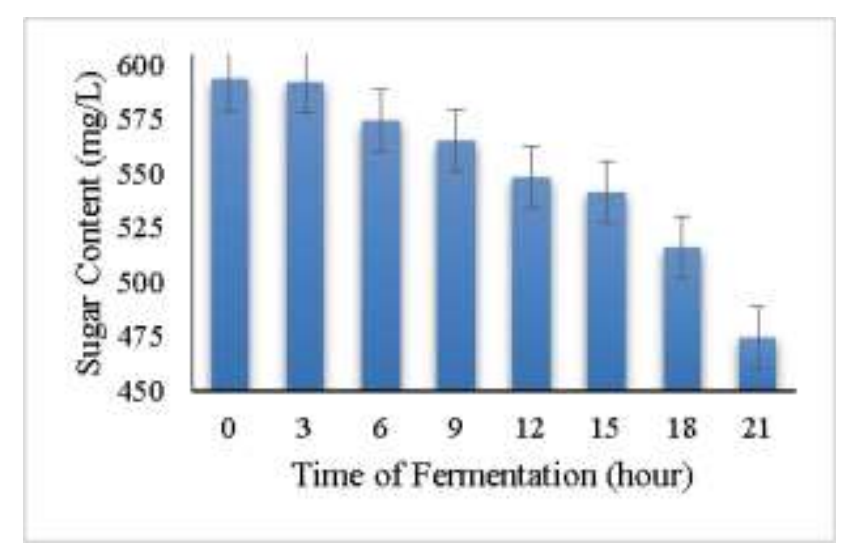

(a)

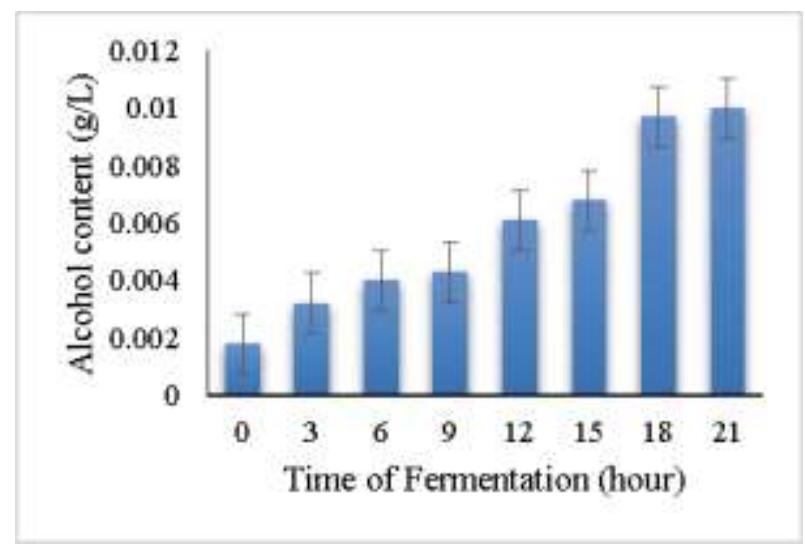

(b)

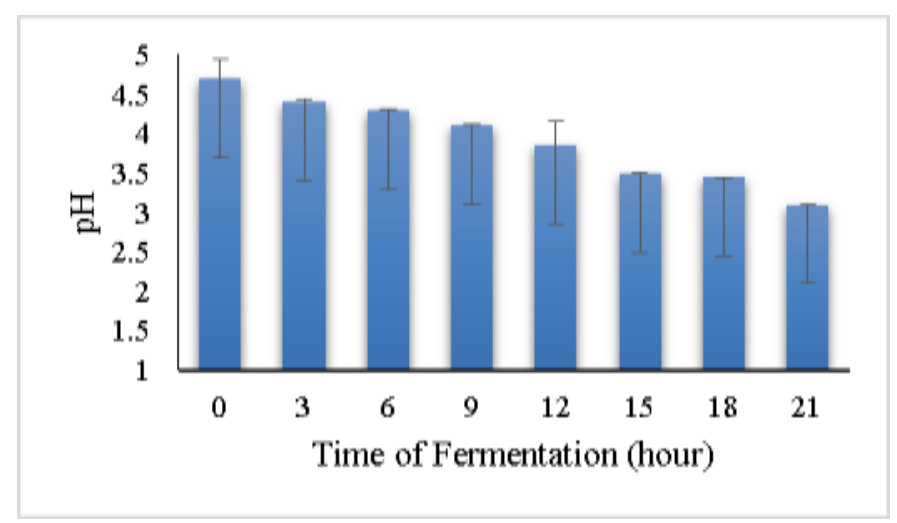

(c)

Figure 3. The changes of sugar (a) and ethanol contents (b) and pH value (c) during Ambonese arrack fermentation

This research has identified microbes in Ambonese arrack fermentation that have never been done before. These microbes, especially yeast, can be used as a starter in the processing of various fermented beverages. Ambonese arrack fermentation also involves a numbers of microbial contaminants, so that the processing of this fermented beverage must be done aseptically to obtain high sensory quality. Microbes found in Ambonese arrack can enrich the knowledge of food microbiology in Indonesia.

\section{CONCLUSION}

Uncontrolled Ambonese arrack processing causes many microbes to be involved in the fermentation. These microbes were succession as the increase in fermentation time. The dominant microbes in this traditional beverage were yeasts, i.e. Pichia polymorpha and Kloeckera javanica. Bacillus were also found in fermentation, but only in the initial stage, so it was considered as contaminant bacteria. The sugar content and $\mathrm{pH}$ value decreased, whereas ethanol content increased during fermentation of Ambonese Arrack

\section{ACKNOWLEDGEMENTS}

The researchers was very grateful to the head and staff of the Microbiology Laboratory of Bandung Institute of Technology who have identified microbes in this research, and Maluku Government, who has provided the funding for the researchers to conduct this research.

\section{REFERENCES}

Albertin, W., Setati, M.E., Miot-Sertier, C., Mostert, T., Colonna, B., Coulon, J., Girard, P., Moine, V., Pillet, M., Salin, F., Bely, M., Divol, B. \& Masneuf-Pomarede, I. (2016). Hanseniaspora ovarum from winemaking environment show spatial and temporal genetic clustering. Front Microbiol, 6, 1-16

Albrecht, A.G., Peuckert, F., Landmann, H., Miethke, M., Seubert, A. \& Marahiel, M.A. (2011). Mechanistic characterization of sulfur transfer from cysteine desulfurase SufS to the iron-sulfur scaffold SufU in Bacillus subtilis. FEBS Letters, 585, 465470

Asakai, T. \& Hioki, A. (2011). Investigation of iodine liberation process in redox titration of potassium 
iodate with sodium thiosulfate. Anal Chim Acta, 689, 34-38

Barlianti, V., Dahnum, D., Muryanto., Triwahyuni, E., Aristiawan, Y. \& Sudiyani, Y. (2015). Enzymatic hydrolysis of oil palm empty fruit bunch to produce reducing sugar and its kinetic. Menara Perkebunan, 83(1), 37-43

Bekker, M.Z., Smith, M.E., Smith, P.A. \& Wilkes, E.N. (2016) Formation hydrogen sulfide in wine: interactions between copper and sulfur dioxide. Molecules, 21, 1-17

Belda, I., Ruiz, J., Esteban-Fernandez, A., Navascues, E., Marquina, D., Santos, A. \& Moreno-Arribas, V. (2017). Microbial contribution to wine aroma and its intended use for wine quality improvement. Molecules, 22, 1-29

Chandrasekhar, K., Sreevani, S., Seshapani, P. \& Pramodhakumari, J (2012). A review on palm wine. Int J Res Biol Sci, 2(1), 33-38

Chandrasena, G., Keerthipala, A.P. \& Walker, G.M. (2006). Isolation and characterization of Sri Lankan yeast germplasm and its evaluation for alcohol production. J Inst Brew, 112(4), 302-307

Chaves-Lopez, C., Serio, A., Grande-Tovar, C.D., Cuervo-Mulet, R., Delgado-Ospina, J. \& Paparella, A. (2014). Tradition fermented foods and beverages from a microbiological and nutritional perspective: the Colombian heritage. Comp Rev Food Sci Food Safe, 13, 1031-1048

Danmadami, R.N., Yabaya, A., Yahaya, O., Abraham, O.J., Bobai, M. \& Orukotan, A.A. (2017). The efficiency of Saccharomyces cerevisiae strain isolated from palm wine in the production of $\mathrm{Bu}$ rukutu. Int J Res Grant, 5(11), 70-85

Escalante, A., Gomez, M.G., Hernandez, G., Aguilar, M.S.C., Munguia, A.L., Gosset, G. \& Bolivar F. (2008). Analysis of bacterial community during the fermentation of pulque, a traditional Mexican alcoholic beverage using a polyphasic approach. Int J Food Microbiol, 124, 126-134.

Gbrikon, G.M., Ichor, T. \& Omeche, E.T. (2016). Effect of bitter leaf extract (Vernonia amygdalina) on culturable microorganisms isolated from palm wine in Makurdi metropolis. Res J Microbiol, 11(4-5), 112-118

Gunawan, L.S. (2019). Korelasi rasio aspartate aminotransferase - alanine aminotrasferase dengan profil hematologi pada peminum alcohol. J Biomedika, 12(1), 26-40

Kalaiyarasi, K., Sangeetha, K. \& Rajarajab, S. (2013). A comparative study on the microbial flora of the fresh sap from cut inflorescence and fermented sap (toddy) of Borrassus flabellifer Linn (palmyrah tree) and of Cocos nucifera Linn (coconut tree) to identify the microbial fermenters. Int J Res Pure Appl Microbiol, 3(3), 43-47
Kim, S.A., Kim, N.H., Lee, S.H., Hwang, I.G. \& Rhee, M.S. (2014). Survival of foodborne pathogenic bacteria (Bacillus cereus, Escherichia coli 0157:H7, Salmonella enterica Serovar typhimurium, Staphylococcus aureus, and Listeria monocytogenes) and Bacillus cereus spores in fermented alcoholic beverages (beer and refined rice wine). J Food Prot, 77(3), 419-426

Kleijn, R.J., Buescher, J.M., Le Chat, L., Jules, M., Aymerich, S. \& Sauer, U. (2010). Metabolic fluxes during strong carbon catabolite repression by malate in Bacillus subtilis. J Biol Chem, 285(3), 1587-1596

Law, S.V., Abu Bakar, F., Hashim, M. \& Abdul Hamid, A. (2011). Popular fermented food and beverages in Southeast Asia. Int Food Res J. 18, 475484

Le, H, D,T. \& Le, V.V.M (2014). Effect of initial $p H$ value of medium on the alcoholic fermentation performance of Saccharomyces cerevisiae cells immobilized on nipa leaf sheath pieces. Songklanakarin J Sci Technol, 36(6), 663-667

Nair, G.R. \& Raja, S.S.S. (2018). Climate and soil properties influence species diversity of soil Bacillus community in India. Microbiol Insights, 11, 1-7 Nwaiwu, O. \& Itumoh, M. (2017). Chemical contaminant associated with palm wine from Nigeria are potential food safety hazards. Beverages, 3(16), 112

Ohimain, E.I. (2016). Methanol contamination in traditionally fermented alcoholic beverages: the microbial dimension. Springers plus, 5, 1-10

Okanlawon, B.M., Ogunbanwo, S.T. \& Okunlola, A.O. (2010). Growth of Bacillus cereus isolated from some traditional condiments under different regimens. Afr J Biotechnol, 8(14), 2129-2135

Olowonibi, O.O. (2017). Isolation and characterization of palm wine strain of Saccharomyces cerevisiae potentially useful as bakery yeast. Eur J Exp Biol, 7(2), 1-13

Roosdiana, A., Prasetyawan, S., Mahdi, C. \& Sutrisno. (2013). Production and characterization of Bacillus firmus pectinase. J Pure App Chem Res, 2(1), 35-41

Sabri, A., Leroy, P., Haubruge, E., Hance, T., Frere, I., Destain, J. \& Thonart, P. (2011). Isolation, pure culture and characterization of Serratia symbiotic asp. Nov., the R-type of secondary endosymbiont of black bean aphid Aphis fabae. Int J Syst Evol Microbiol, 61, 2081-2088

Sahusilawane, A.M., Uluputty, M.R., Kembauw, E. \& Joko, S.W. (2015). Hapa, suatu kearifan local suku Meher di Pulau Kisar dalam menjaga ketahanan pangan. J Penel Kesejah Sos. 14(3), 305-316. 
Sudha, R., Niral, V., Hebber, K.B. \& Samsudeen, (2019). Coconut inflorescence sap. Curr Sci, 116(11), 1809-1817

Vengadaramana, A., Uthayasooriyan, M., Sittampalam, T., Razeek, N. \& Kapilan R. (2016). The characterization of amylolytic enzyme present in fermented sweet sap of palmyrah. J App Biol Biotechnol, 4(3), 20-23

Zhu, Y., Zhang, F., Zhang, C., Yang, L., Fan, G., Xu, Y., Sun, B. \& Li, X. (2018). Dynamic microbial succession of Shanxi aged vinegar and its correlation with flavor metabolites during different stages of acetic acid fermentation. Sci Rep, 8, 1-10. 